\title{
Methods of Logistic Infrastructure Formation for Enterprises Manufacturing Bottled Water
}

\author{
Dana Vyacheslavovna Chernova ${ }^{1}$, Natalia Ivanovna Voytkevich ${ }^{1} \&$ Natalya Vasilyevna Ivanova ${ }^{1}$ \\ ${ }^{1}$ Samara State University of Economics, 141 Sovetskoi Armii St., Samara, 443090, Russia \\ Correspondence: Natalya Vasilyevna Ivanova, Samara State University of Economics, 141 Sovetskoi Armii St., \\ Samara, 443090, Russia.
}

Received: August 13, 2014

Accepted: November 6, 2014 Online Published: February 12, 2015

doi:10.5539/ass.v11n5p274

URL: http://dx.doi.org/10.5539/ass.v11n5p274

\begin{abstract}
The modern post-industrial level of development of social-economic relations implies the primacy of services, intensification of scientific-technical progress, as well as the integration of economic operators, including in the sphere of production. Functioning of the industrial enterprises is impossible without a developed logistics infrastructure, the formation of which is connected with the adoption of managerial decisions on the composition of its elements and their geographic location. Decision-making process on the composition and quantity of infrastructure objects should be based on the mathematical modeling. In today's economy, it is vitally important to the formation of the logistics infrastructure of enterprises, oriented to meet the demand of end users. In particular, this area is the production of bottled drinking water, which is relatively new for Russia. The bottled drinking water market is one of the fastest-growing in Russia, and water is a world strategic resource. To optimize the process of formation of the logistics infrastructure of enterprises for the production of bottled drinking water is possible by application of the principles of logistics. The above determines the importance of the topic of the issue, its theoretical orientation and practical significance. Multivariate analysis is a tool that reveals the relationship between a number of external and internal factors and the composition of objects logistics infrastructure. Based on these factors through multivariate regression analysis were constructed mathematical model for determining the composition of the elements of the logistics infrastructure.
\end{abstract}

Keywords: logistic infrastructure, mathematical modeling, bottle water manufacturing, multiple factor analysis (MFA), correlation analysis, Pareto analysis

\section{Introduction}

Bottled water manufacturing is a relatively new kind of business for Russia. It began to develop actively in the 90 's, before that on the market there existed bottled kinds of mineral water meant for medical treatment. Potable water supply reduction, ecological situation aggravation and income growth of population will promote bottled water manufacture development. At present time on average every third tap water sample in Russia does not meet sanitary and chemical criteria and every tenth one does not meet sanitary and bacteriological requirements. Nevertheless, bottled water consumption in Russia falls behind Europe.

Geographically bottled water consumption in the world is distributed in the following way: $64 \%$ of bottled water are consumed in Europe, 21\% - in the USA, 3,5\% - in the Eastern countries and 11,5\% account for the rest of the world (Rynok pitievoy vody, 2012).

As of today there are more than 500 companies in the Russian bottled water market, a part of them is non-resident. Their business requires a developed logistic infrastructure maintaining operation of the enterprises.

The market of bottled potable and mineral water (Bottled Water Industry Market Research Reports. 2013; Fasullina, 2006; Rossiskiy rynok vody pokazyvaet uverennii rost, 2012) today is one of the most fast-developing one. According to the data provided by Russian Union of Nonalcoholic Beverages Producers its rate of growth in the recent 4 years is keeping the level of $20 \%$, on a short-term horizon this segment will grow at least to $50 \%$ and its potential will not be exhausted: in Russia average annual consumption per person amounts according to the different estimates from 15 to 33 liters of bottled water, whereas in Poland it is 40, in Czech Republic - 50, and in Western Europe the average is 70 liters (Figure 1). Considerable growth pace as the bottled water producers 
think is caused by the income growth of the population and responsible consumption development (Bottled Water Industry Market Research Reports, 2013).

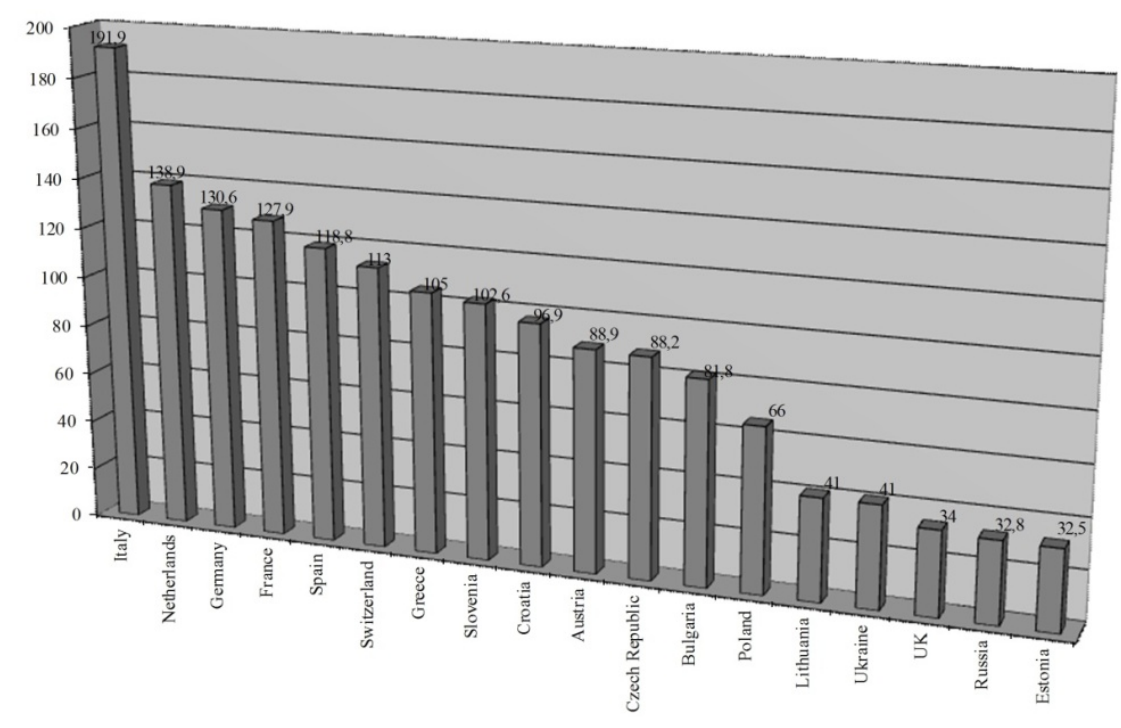

Figure 1. Level of consumption of bottled drinking water in Europe, 1/person per year

\section{Materials and Methods}

Long time was considered that the production of water is a local business, since it is "tied" to the source, but there were created a number of international brands - Perrier, Vittel, Evian, San Pellegrino, Volvic, and The Nestle company has created the first global brand Pure Life drinking water from the reverse osmosis method or steam distillation with subsequent remineralization (Senior \& Dege, 2005).

Above mentioned global and international brands that need to be distinguished. The global (world) brands brands produced around the world, is tied to the markets; international brands, first of all, this brand of luxury apartments, which are delivered from the historical places of production (bound to the very source) to the markets around the world.

Because of a considerable logistics costs (mostly transport), costs distributors Federal producers cannot offer the market the product in the low price segment.

It should be noted that over the last 2-3 years a tendency for a larger market their own product local producers, organization of sales in the neighboring regions. In this regard, local companies begin to form the structure of sales, which in its main characteristics resembles the structure of the Federal producers (OOO "Standartprommash Service". Official website, 2010).

According to research company Intesco Research Group, the share of imported water in the structure of consumption of bottled water in Russia in 2011 amounted to 3\% of total consumption. The main share in total imports is premium water from France - 45\% (Rossiskiy rynok vody pokazyvaet uverennii rost, 2012).

The leading world producers of bottled water are four companies: Nestle Waters, Danone, Coca-Cola and PepsiCo. The share of these companies in the world market in 2002, reached $30 \%$ and continues to grow each year.

Leading global bottled water producers are four companies: Nestle Waters, Danone, The Coca-Cola Company and PepsiCo Inc. The share of these companies on the global market at present forms about $40 \%$.

On the Russian potable water market there are many global and international brands - both relatively low-price brands Vera, Bon Aqua, Aqua Minerale and premium water Perrier, Evian, Vittel, Thonon, Volvic, Pier Val, SPA and Valvert.

A special feature of Russian water market is its fragmentary character: according to different estimates $30-40 \%$ of sales are controlled by two transnational companies - Pepsi Bottling Group (Aqua Minerale) and Coca-Cola Company (BonAqua). Other leading producers - Nestle Waters (Saint Spring, Perrier, Vittel, San Pellegrino), 
Shishkin Les Holding (Shishkin Les) and Visma (Arhyz) company comprise 3-7\%, the rest belongs to 650 local brands (Fasullina, 2006).

It is worth noting that according to the research carried by marketing agencies the dominating position on the Russian market of potable and mineral water is occupied by domestic water producers. Thus summarizing the results of 2010 the proportion of import production in volume terms comprised only 1, 6\% (Kalachev ans Jakubauskas, 2011; The fighting of producers of mineral and artesian water, 2013), and in $2011-3 \%$ (Rynok pitievoy vody, 2012; Zenith International Ltd, 2012).

The companies conducting their business on the Russian market of potable bottled water act on different levels (local, regional, federal, international) and as a result their logistical channels differ as well. Regarding this fact it is useful to take a close look at trade channels of the enterprises producing bottled water (Figure 2).

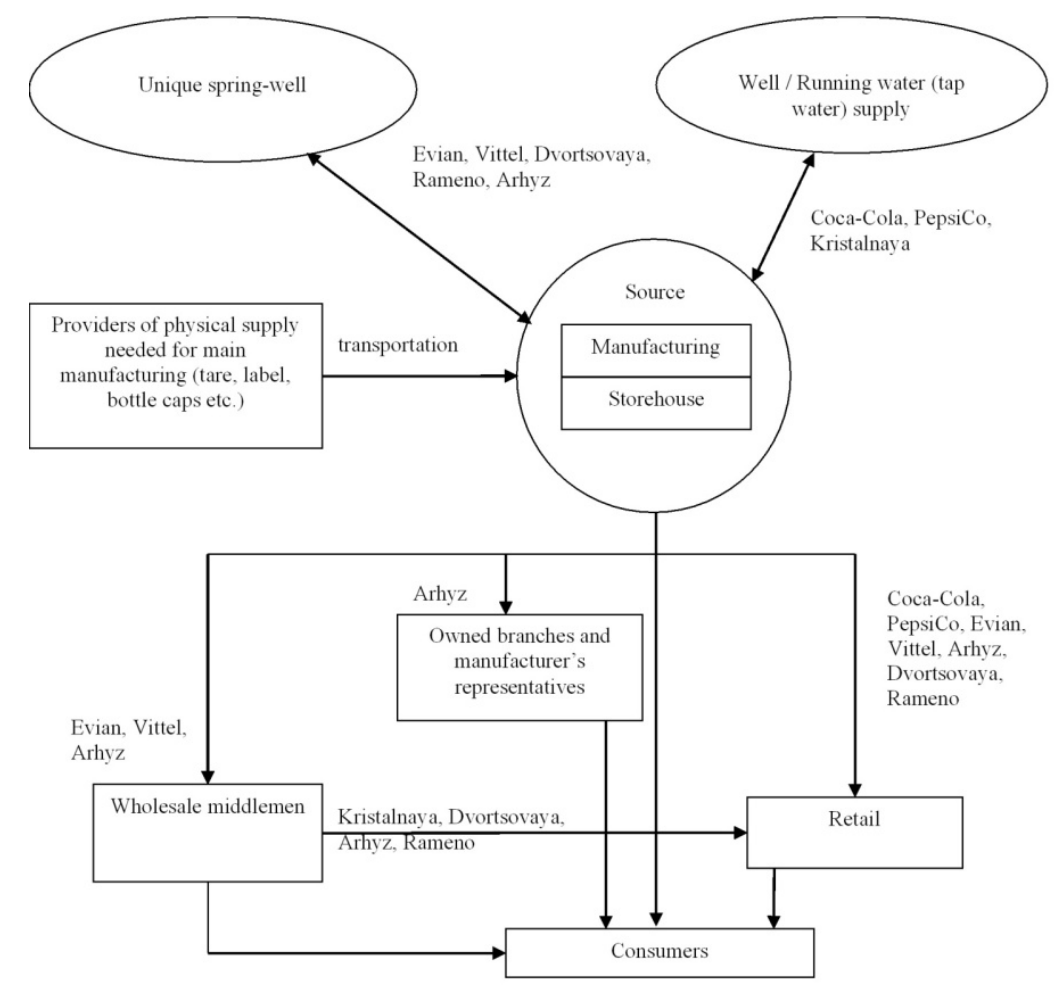

Figure 2. Logistic channels of the bottled potable water manufacturing enterprises

There are few types of enterprises producing bottled potable water: enterprises, which place a priority on the uniqueness of the spring-well and possess manufacturing facilities in close proximity to it (they distribute their products directly as well as with the help of middlemen including sales on international markets); and also there are enterprises focused on distribution areas (international activities are connected with productions establishment on the local markets).

Dissemination of products through a retail trade network is typical for Federal and international brands, and delivery to the house and into the office for local, but there are brands that use both sales.

For example, such companies as Coca-Cola, PepsiCo, Evian, Vittel and many others have chosen the first option is spread through the trading network, such companies on the Samara market as Crystal, Laguna chose the delivery of water, such as the Palace, Rameno, Arkhyz use both.

Manufacturers mentioned that the bottled water market in Russia is still heavily exposed to seasonal fluctuations. Water is not included in the mandatory consumer basket of Russians.

It should also be noted that this market is characterized by a large number of competitors, the availability of substitute products, inform consumers about the sellers and prices, and most importantly - the goods is not an essential commodity. According to the research company Intesco Research Group, in the structure of retail sales of non-alcoholic beverages bottled mineral and drinking water is $36 \%$, juices - $25 \%$. Largest share of sweet soft drinks. The least account for the sale of tea, sports and energy drinks (Union of producers of bottled water. 
Official website, 2013). All these factors indicate that the elasticity of demand and costs is very high. According to specialists it is from 3,5 to 4,5 (Gadaev, 2012).

Regardless of the uniqueness of the spring the manufacture is situated approximate to the natural water source as it is required by the World Health Organization (WHO) that prohibits transportation of potable, natural and mineral water by considerable distance to the place of bottling and packaging.

All necessary materials - tare (nineteen-liter bottles) or preforms for on-site bottles insufflating, labels, bottle caps, etc. are delivered to the manufacturing site. It is important to mention that only potable bottled water producers that are oriented at unique spring can have maximum possible number of distribution channels: end product is delivered to retail trade networks, an alternative is creating of owned branches and manufacturer representatives (cooperation with wholesale middlemen is also possible) which are occupied with immediate distribution (through retail networks or using home or office delivery).

Potable bottled water producers oriented at sales market in their turn can distribute the product both using retail trade and directly deliver it to homes and offices.

However, in the latter case the enterprises not just use an alternative channel but they become members of a separate market - Home and Office Delivery (HOD) market.

Today one of the few ways of competition in this market is the provision of additional services. And, first of all, it is expedient to speak about the services on delivery of water to your home or office.

Generally, producers of bottled drinking water have different target segments and strategies on the market, it is necessary to note the fact that manufacturers to deliver at home and in the office, is market participants HOD (Home \& Office Delivery).

Work in the market of delivery of drinking water and, consequently, infrastructure enterprises, has a number of features: in addition to the production, to organize delivery of the required own truck fleet, call-center, service center on service of the equipment (pumps, coolers, dispensers), logistics Department, developing the optimal delivery routes.

Another feature of the market of water delivery to offices and homes is an out of season consumption. This is one of the factors that forced many manufacturers mineral and potable water to show interest to the HOD market.

While forming proposals for companies for the delivery of water should be taken into account consumers ' preferences regarding the equipment for bottling water. As companies increasingly operate on two market segments (households (B2C) and enterprises (B2B), and consumer preferences are different.

These channels provide opportunities for product promotion, creation of favorable impression of him, and thus attract new consumers.

Product distribution with the help of retail trade networks is characteristic of federal and international brands whereas home and office delivery - of local ones; nevertheless, there are some brands which make use of the both sales variants.

From the characteristics of Russian potable bottled water market it follows that the enterprises activities have a range of special features which created a cause for suggestion of new formation methods for its logistic infrastructure:

1. potable bottled water market in Russia is under saturated and it is actively growing;

2. the market is occupied with many local as well as foreign companies and their activities are impossible without a developed logistic infrastructure;

3. at present there is a lack of any research in this field. Besides the mentioned characteristics the main factor serving as a foundation for the given research is that at present time in Russia the growth of potable bottled water market is connected with the expanding of production capacity which is reached by new enterprise creations. The number of projects concerning plants construction manufacturing potable bottled water at the moment is about 100 .

In this regard there was carried out a research aimed at model construction for formation of effective logistic infrastructure (Christopher, 2005; Mirotin et al., 2005; Stock \& Lambert, 2000) objective contents for potable bottled water manufacturing. The algorithm of the research is made using the scheme provided in Figure 3 .

The essence of these methods lies in the combination of two instruments: Pareto analysis which helps to identify range of factors influencing the decision making concerning enterprise logistic infrastructure objective 
composition and multiple correlation regression analysis which helps to identify the necessary number of logistic infrastructural objects of each type.

It is worth noting that the analysis was carried out on the basis of secondary information sources (official data from the companies, publications in mass media, reports etc.) which are characterized by their heterogeneity. This characteristic feature in particular has influenced the choice of the instruments for the analysis.

Stage 1. In the framework of factors analysis influencing the logistic infrastructure (Swamidass, 2000) object formation in the enterprises manufacturing potable bottled water there were studied twenty five plants construction projects in this sphere which at the moment are on various stages of realization (from planned to brought into operation) located in several regions of Russia and possessing different volumes of water extraction and bottling.

Stage 2. According to the provided data there were singled out the following groups of factors: characteristic features of the manufacturing process; availability of infrastructural elements in the prospective enterprise construction place (it refers to transport objects of the infrastructure, power transmission line etc.); situation on the market(competitiveness existence and level); availability of qualified staff and manufacturing technology (this factor also includes modern information transmission technologies).

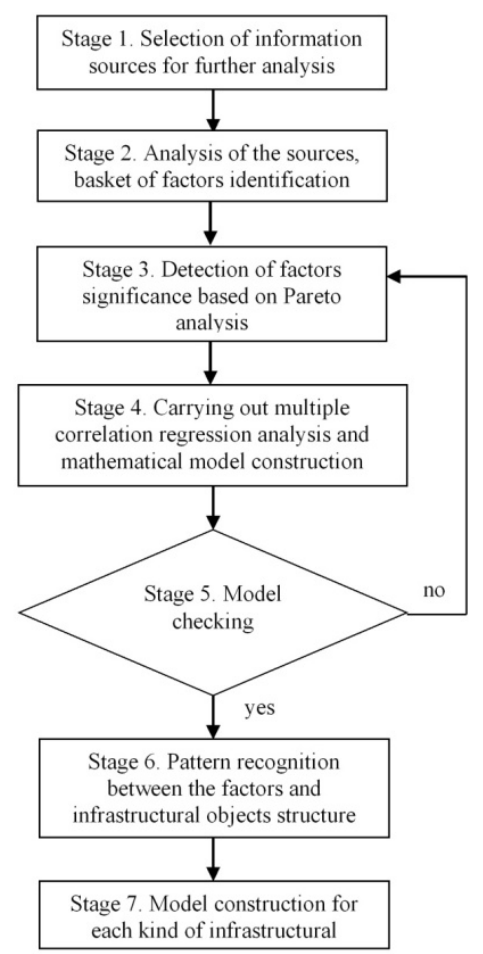

Figure 3. Mathematical models formation algorithm covering the dependence of manufacturing logistical infrastructure indicators in enterprises manufacturing potable bottled water from influence of internal and external factors

Stage 3. The most frequently mentioned factors are the availability of infrastructure $(34,92 \%)$ and the availability of resources $(31,75 \%)$, however, the last factor is mentioned only in projects for the production of water. On the basis of this grouping, it is advisable to build a Pareto diagram.

To carry out the analysis there was constructed a Pareto diagram (Figure 4), in accordance with it the three factors in total represent $84,13 \%$. These are such factors as: presence of infrastructural elements, availability of the resources and special features of the manufacturing process. At the same time the situation on the market, technology and labor force constitute a considerably minor part and as a result have a minor significance.

Most of the projects of the construction of factories for the production of bottled drinking water are the investment projects, they have a significant contribution to the development of the regional economy and the industry in general. At the same time, the construction of such plants requires significant financial investments. 


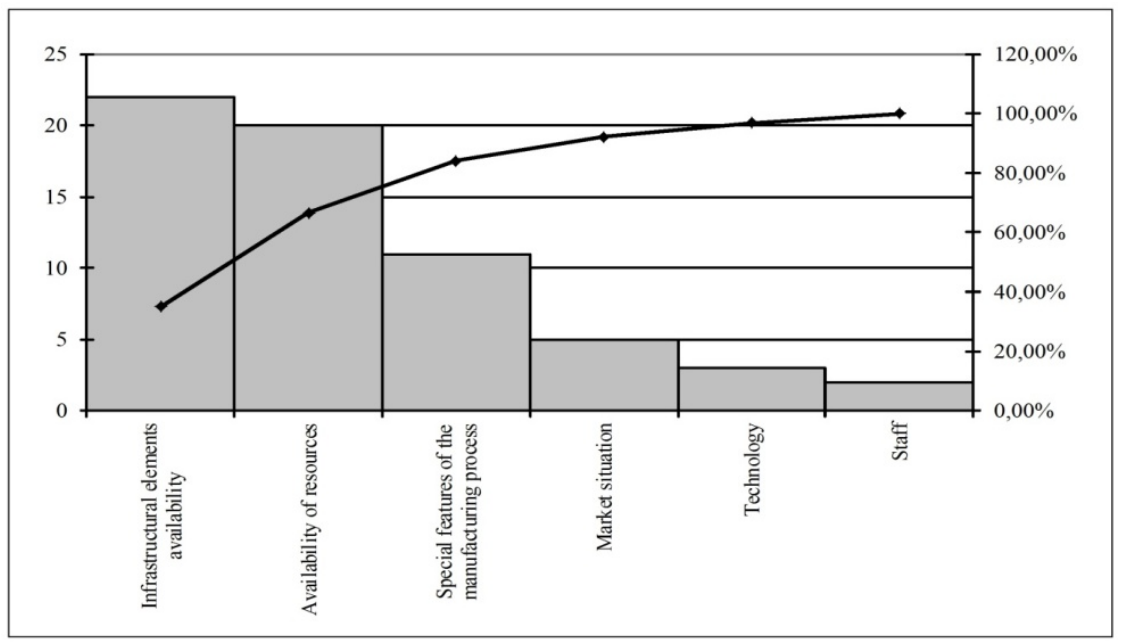

Figure 4. Pareto diagram: degree of the impact produced by the factors

Stage 4. Before constructing a multifactor regression model of resultative character (production volume) first there were selected factorial criteria for the model. In order to do this there was constructed a matrix of paired correlation factors.

As seen from Table 1 only the coefficients of the factors $X 1$ and $X 2$, large enough for the module, the remaining coefficients have values less than 0.3 , which means a weak link with effective sign. The multicollinearity factors $\mathrm{X} 3$ and $\mathrm{X} 4$, as the pair correlation coefficient more than 0.8 , we can say that they have a reverse functional dependence (since pair correlation coefficient is negative and almost equal to one). Thus, given the model signs $\mathrm{Y}, \mathrm{X} 1, \mathrm{X} 2$.

Table 1. The pair correlation coefficients matrix

\begin{tabular}{lrrrrrr}
\hline & $Y$ & \multicolumn{1}{c}{$X 1$} & $X 2$ & $X 3$ & $X 4$ & \\
\hline $\mathrm{Y}$ & 1,000 & & & & & \\
$\mathrm{X} 1$ & 0,538 & 1,000 & & & & \\
$\mathrm{X} 2$ & 0,546 & 0,386 & 1,000 & & & \\
$\mathrm{X} 3$ & 0,031 & 0,291 & $-0,012$ & 1,000 & & \\
$\mathrm{X} 4$ & $-0,035$ & $-0,295$ & 0,002 & $-0,999$ & 1,000 & \\
$\mathrm{X} 5$ & 0,125 & 0,140 & 0,307 & 0,025 & $-0,058$ & 1,000 \\
\hline
\end{tabular}

Next, we need to compose a matrix of values of these characteristics and to carry out calculation of multidimensional regression.

As seen from Table 1, multiple correlation coefficient $\mathrm{R}=0,651$, while $\mathrm{F}=8,089$, and the significance level of alpha is $0,002<0.05$, which confirms the importance of $R^{2}$.

Consequently, the correlation coefficient is significant, the link between effective sign and a set of factor topics included in the regression model, a close.

After multicollinearity check there were added criteria $\mathrm{y}$ (production volume), $\mathrm{x}_{1}$ (investment size), $\mathrm{x}_{2}$ (the number of employees) to the model.

Production volume variance for average $42,38 \%$ can be explained by the factorial criteria variance included to the model (investment size and employees number).

Though this value is very small less than a half of the variance is explained by means of factors included to the model. In turn including of the rest studied criteria to the model makes no sense because their connection with the resultative criterion is very weak. Thus it is possible to make a conclusion that there exist some other factors influencing on the resultative criteria though in the course of the research they were not revealed as they are not mentioned in the information sources. 
Consequently there was developed a hypothesis that the factors which determine the production volume can be the following: debit of the source, size of production premises, manufacturing line speed, number of lines etc.

Based on the calculations there was made a regression equation:

$$
y=-63480,55+70,748 x_{1}+1317,7 x_{2}
$$

In this case the values of the factors regression coefficients $x_{1}$ and $x_{2}$ are positive and consequently the link is also positive. From this it follows that the increase of investment size and staff number results in the increase in production volume.

Stage 5. The obtained equation can be used for production volume forecasting for projected enterprises on the condition that the factorial criteria values do not go beyond the limits of given data interval of the model. However, after the model check it was pointed out that the production volume magnitude will be a positive value only if the investment size is substantial (not less than 750 million rubles) and the number of staff is not less than 8 people. It is obvious from the constructed model that the value of resultative criterion is determined by the two factors from all considered ones.

We determined the dependence of the output from a combination of factors and received in the result of a mathematical model, but in this study, the task was to evaluate the degree of influence of factors on the structure of the logistics infrastructure. On the basis of empirical data, you can build a model for each type of infrastructure.

Stage 6. Using the data of the enterprises there were compared the factors influencing on the contents of the logistic infrastructure objects and directly on the sum-total of the logistic infrastructure objects.

Stage 7. There were calculated the paired correlation coefficients for each type of infrastructural objects and the regression equations were made (Table 2).

\section{Results}

Table 2 shows the results of the issue. We denote the necessary area of land as $y_{1}$, production area $y_{2}$, warehouse area $y_{3}$ and the roads to major highways $y_{4}$, all factor signs, let $x_{1}, x_{2} \ldots x_{6}$.

Table 2. The results of the correlation-regression analysis for each type of logistic infrastructure objects in enterprises manufacturing potable bottled water

\begin{tabular}{ccccc}
\hline \multirow{2}{*}{ Infrastructural object } & \multicolumn{3}{c}{ Results of the calculation } \\
\cline { 2 - 4 } & $\begin{array}{c}\text { Multiple correlation } \\
\text { coefficient }\left(\mathrm{R}_{\mathrm{B}}\right)\end{array}$ & $\begin{array}{c}\text { Significance } \\
\text { value(F } \alpha \mathrm{p})\end{array}$ & $\begin{array}{c}\text { Determination } \\
\text { coefficient }(\mathrm{D})\end{array}$ & $\begin{array}{c}\text { Regression } \\
\text { equation }\end{array}$ \\
\hline $\begin{array}{c}\text { Land plot area }\left(y_{1}\right) \\
\text { Manufacturing premises }\end{array}$ & 0,921 & $0,00<0,05$ & $84,9 \%$ & $\mathrm{~A}^{*}$ \\
area $\left(y_{2}\right)$ & 0,878 & $0,00<0,05$ & $77,0 \%$ & $\mathrm{~B}^{*}$ \\
Storage premises area $\left(y_{3}\right)$ & 0,875 & $0,00<0,05$ & $76,6 \%$ & $\mathrm{C}^{*}$ \\
$\begin{array}{c}\text { Stretch of the roads to the } \\
\text { main highways }\left(y_{4}\right)\end{array}$ & 0,354 & $0,41>0,05$ & $12,5 \%$ & - \\
\hline * Regression equation A $y_{1}=0,81+0,001 x_{1}+0,06 x_{3}+0,007 x_{5}+2,097 x_{6}$ \\
B $y_{2}=470,52-0,084 x_{1}+0,001 x_{2}+6,21 x_{3}-3,49 x_{5}+48,74 x_{6}$ \\
C $y_{3}=844,83-0,179 x_{1}+0,001 x_{2}+8,57 x_{3}-6,14 x_{5}+141,23 x_{6}$ &
\end{tabular}

It is important to mention that there is an evident interdependence between such indicators as the required land plot area, manufacturing premises area and storage premises area. On average the manufacturing area comprises about $1,74 \%$ from the total land plot area, the storage area comprises $2,93 \%$.

Such ratio is conditioned mainly by the fact that a significant area of the total is occupied by a sanitary zone or spring protection zone which according to international standards can reach the size of source water catchment area.

This means that the significant part of the land stays in fact untapped but at the same time it requires a considerable volume of money for maintenance of this area.

There is a certain interdependence between the production volume and the required areas because depending on the productive capacity the data differs (Figure 5). 
This means that for the enterprises having production volume from 8,9 million liters per year to 1000 million liters per year the manufacturing premises area on average occupies $1,05 \%$ from the total area while the storage area is $1,51 \%$, in other words they correlate as 5 to 7 . For the enterprises with production volume from 1000 million liters per year to 10000 million liters per year the manufacturing area in average occupies $2,66 \%$ while the storage area is $4,94 \%$, that means correlation as 4 to 7 .

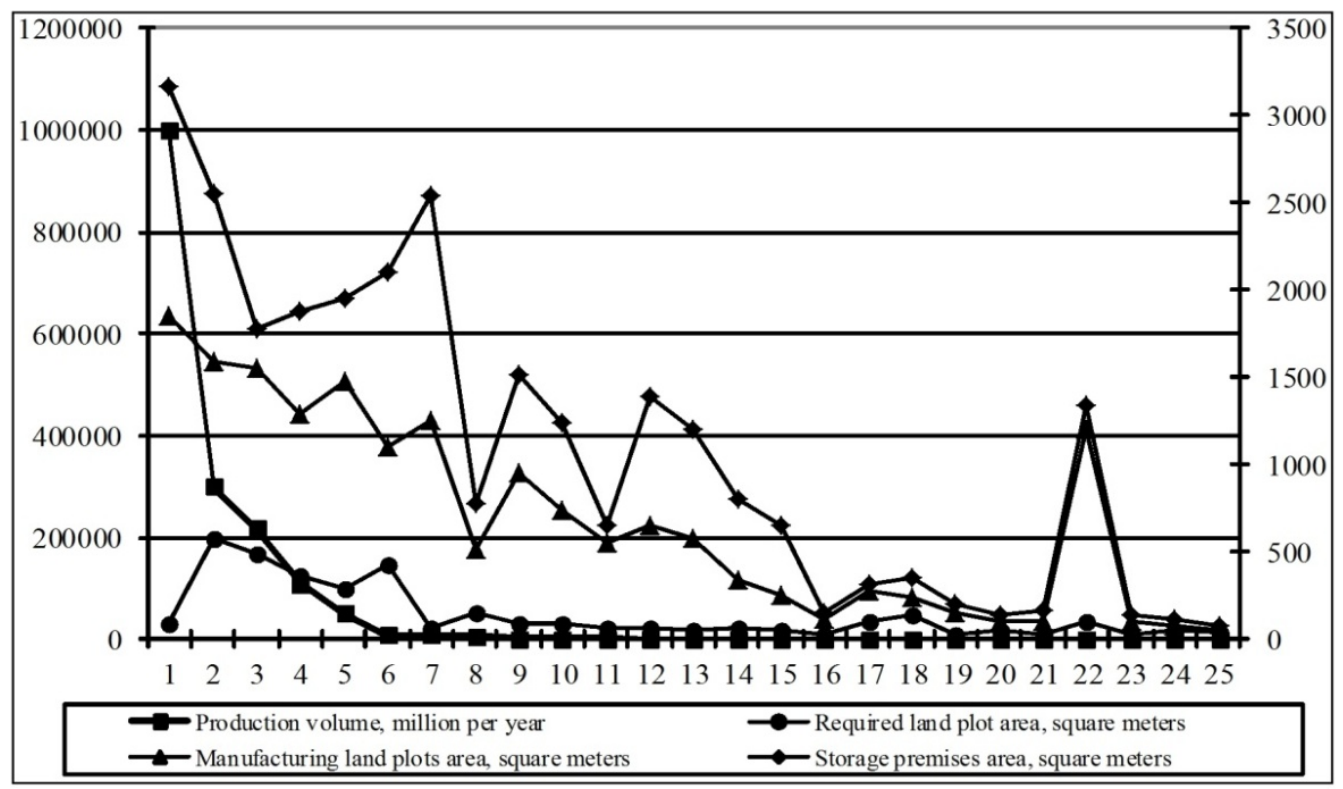

Figure 5. Correlation of the number of infrastructural elements

Having a production volume of 10000 up to 1000000 million liters per year the manufacturing premises area comprises average $1,79 \%$, storage premises area $-2,84 \%$, which makes up correlation as 2 to 3 . In average including all kinds of enterprises the manufacturing area occupies $1,74 \%$, storage area is $2,93 \%$, that is correlation as 2 to 3 .

\section{Discussion}

Today there are many approaches to the definition of infrastructure, however, it became widely used in the economic literature only to the middle of XX century.

Their point of view on the importance of infrastructure in the economy in the late 80-ies of the XX century expressed D. Ashower. Referred Campbell R. McConnell and Stanley L. Brue: “...this economist believes that public investment in infrastructure and private investment functionally interrelated. In other words, the construction of new roads and bridges accelerates the transport of goods from producers to consumers, and the modern power plants reduce the energy consumption and thus total production costs on private enterprises" (McConnell \& Brue, 2001).

M. Porter in "Competitive advantage of Nations", published in 1990 (as well as in later works), included infrastructure in the model of "competitive diamond" as one of factor conditions necessary for the competitiveness of the country: "...the country's position in factors of production such as skilled labor or infrastructure necessary to compete in this industry" (Porter, 2005).

In modern conditions the infrastructure plays a decisive role in the economy in General and in logistics in particular. Availability of infrastructure is a necessary condition for the effective functioning of the logistic system.

Thus, D. Bowersox and D. Kloss note that "competence in logistics is achieved through the coordination of such activities, as (1) the formation of the logistics infrastructure; (2) information exchange; (3) transportation; (4) inventory management; (5) warehousing, handling, packaging. Only consolidated in a single system, these functional areas can meet the needs of logistics.

Typical objects of logistics infrastructure include manufacturing plants, warehouses, loading-unloading terminals and retail stores. Determination of necessary quantity of each type of object, its geographic location and 
economic functions is an essential element of all activities on formation (design) and logistic infrastructure" (Bowersox \& Closs, 2008).

It should be noted that M. Porter and J. Shapiro include the infrastructure in the complex support of activity of the chain of value creation (Shapiro, 2006).

Infrastructure plays a crucial role in the economy and is one of the main factors of competitiveness both at the micro-and macro-level. The development of logistic infrastructure is a major task, as the number, size and location of the infrastructure objects directly affect the level of costs and the level of customer service. In addition, the most important is the ability of the infrastructure to dynamically change depending on the needs of the market and development of scientific-technical means.

We can give the following definition of logistics infrastructure: logistics infrastructure is a set of external and internal objects, technical, social, institutional and informational infrastructure for the movement of material, including related financial and information flows in the process of procurement, production and distribution of economic sub-projects within their logistics activities.

During the research it was found that the formation of the logistics infrastructure is influenced by a combination of factors. In turn, the process of making decisions on the composition of the infrastructure is quite complex. Therefore, in this study an attempt was made to simulate this process by using mathematical methods.

Correlation-regression analysis was not chosen accidentally: it allows to determine the impact of factors on successful sign. There are many works devoted to the regression analysis (Dielman, 1991; Draper \& Smith, 1981; Kleinbaum \& Kupper, 1978; Neubauer, 2011; Neubauer, 2011). However, with regard to infrastructure and the process of its formation these methods to date were not applied. The proposed model is not ideal, but at the same time - this is the first attempt of defining such dependencies production logistics, which certainly includes the further development and improvement.

\section{Conclusions}

To sum up it is important to mention that in the framework of the research there was analyzed interconnection between the factors of logistic infrastructure formation in the enterprises producing potable bottled water; mathematic models for parameters calculation of each types of objects were constructed and the dependence between the required area size for infrastructural objects and production capacity was defined. Based on the provided data there were calculated correlations between the production volume and the required areas for infrastructural objects. This represents the methods of infrastructure projection and structuring for the enterprises of the given sphere.

\section{References}

Bottled Water Industry Market Research Reports. (2013). Retrieved October 7, 2013, from http://www.reportlinker.com/p0960705/Bottled-Water-Russia.html

Bowersox, D. J., \& Closs, D. J. (1996). Logistical Management: The Integrated Supply Chain Process (p. 48). McGraw-Hill Companies Inc.

Christopher, M. (2005). Logistics and Supply Chain Management: Creating Value-adding Networks (3rd ed., p. 13). Pearson Education.

Dielman, T. E. (1991). Applied regression analysis for business and economics (p. 118). PWS-Kent Pub. Co.

Draper, N., \& Smith, H. (1981). Applied regression analysis (p. 13). Wiley.

Fasullina, A. (2006). Water balance. Retrieved July 1, 2013, from http://www.adme.ru/bonaqua/vodnyj-balansvneshnij-vid-56642/

Gadaev, M. (2012). Analytical review. Market research and analysis of the sales of mineral water. Retrieved January 12, 2012, from http://www.regionkmv.ru/waters/market.html

Kalachev, S. L., \& Jakubauskas, A. N. (2011). State of the Russian market of drinking water and water purification devices. Vestnik of the Russian Trade and Economic University, 5(54).

Kleinbaum, D. G., \& Kupper, L. L. (1978). Applied regression analysis and other multivariable methods North Scituate. Mass.: Duxbury Press.

McConnell, C. R., \& Brue, S. L. (2001). Economics: Principles, problems and policies (13-e ed., Vol. 1, p. 394). Moscow: INFRA-M.

Mirotin, L. B., Korchagin, V. A., \& Lyapin, S. A. et al. (2005). Supply chain in complicated technology 
productions (p. 180). Moscow: Ekzamin.

Neubauer, R. M. (2011). Business Models in the Area of Logistics (p. 15). Wiesbaden: Gabler.

OOO "Standartprommash Service". (2010). Retrieved April 12, 2012, from http://www.press-forms.ru/info/ proizvodst/

Porter, M. E. (2005). Competition (p. 220). Moscow: Williams.

Rossiskiy rynok vody pokazyvaet uverennii rost. (2012). Retrieved May 5, 2013, from http://watermarket.ru/ articles/7403

Rynok pitievoy vody. (2012). Retrieved July 3, 2013, from http://www.newchemistry.ru/printletter. php?n_id=5541

Sen Ashish, K., \& Srivastava, M. S. (1990). Regression analysis: theory, methods and applications (p. 126). Springer-Verlag.

Senior, D., \& Dege, N. (2005). Technology of bottled water (p. 230). Oxford: Blackwell Publoshing Ltd.

Shapiro, J. (2006). Modelling the Supply Chain (p. 36). Translated from English. Edited by V. S. Lukinsky. Saint-Petersburg: Peter.

Stock, J. R., \& Lambert, D. M. (2000). Strategic Logistics Management (4th ed., p. 73). Boston: Irwin McGraw-Hill.

Swamidass, P. M. (2000). Logistics Infrastructure (p. 231). Springer US.

The fighting of producers of mineral and artesian water. (2013). Retrieved July 15, 2013, from http://watermarket.ru/articles/7565

Union of producers of bottled water. Official website. (2013). Retrieved July 28, 2013, from http://www.bwpu.ru/

Zenith International Ltd. (2012). Retrieved August 8, 2013, from http://www.zenithinternational.com/market industry_reports/press_release_detail.asp?id $=290$

\section{Copyrights}

Copyright for this article is retained by the author(s), with first publication rights granted to the journal.

This is an open-access article distributed under the terms and conditions of the Creative Commons Attribution license (http://creativecommons.org/licenses/by/3.0/). 